\title{
Corporate Social Responsibility and Sustainable Development of Modern Russian Companies As A Challenge of Business Globalization
}

\author{
Konstantin Belousov ${ }^{1 *}$ \\ ${ }^{1}$ Saint-Petersburg State University, Faculty of Economics, Department of Economic Theory and \\ Social Policy, 191194 Tchaikovskogo str. 62, Saint Petersburg, Russian Federation
}

\begin{abstract}
This paper investigates comparative analysis in order to trace approaches to interpretation of the content and principles of sustainable development due to increasing number of companies, declaring their commitment to the principles of sustainable development. I review a degree of compliance of Russian companies to international and national standards, relevant to practices of leading companies, a degree of involvement of Russian companies in general sustainable development. Particular interest lays in the study of influence of social responsibility of business, socially responsible sustainable development on the company. This line of research is only beginning to emerge in Russia. Interpretation of corporate social responsibility role allows a different look at the phenomenon of social responsibility and its role in sustainable development. Russian companies quickly accepted the concept of sustainable development, as well as the corresponding terminology. It is important to trace now how basic ideas and principles of sustainable development are reflected in the company's strategy and implemented in practice. By analyzing non-financial reporting I will introduce ways, tendencies and problems of corporate social responsibility implementation by Russian companies.
\end{abstract}

\section{Introduction}

In recent years, the issues associated with sustainable development problems, became a subject of discussion, both at the supra-national and national levels. Steady interest growth in reflected in multiple international initiatives, a large number of scientific publications . As American researchers T. Dyllik and K. Hockerts, actively engaged in research in the field of sustainable development, noticed, "Sustainability has become a mantra for the $21 \mathrm{st}$ century" [1].

Many scholars correctly point out that actuality and relevance of sustainable development research issues are associated with many cognitive, theoretical and practical reasons, with formation of a number of long-term economic and social trends, global risks

*Corresponding author: belloussov@mail.ru 
and challenges, with search for a new model of growth and socio-economic development, with focus on sustainable development is its distinctive feature [2].

Due to increasing number of companies, declaring their commitment to the principles of sustainable development, a comparative analysis of foreign and Russian companies' approaches to interpretation of the content and principles of sustainable development has a particular interest. An analysis of sustainable development approaches, implemented by Russian companies in practice, reveals a number of their characteristic features, as well as determins a degree of compliance of Russian companies and international and national standards, relevant to practices of leading companies, assesses degree of involvement of Russian companies in sustainable development in terms of globalization.

Formation of theoretical foundations of sustainable development of business, of corresponding system of concepts, principles and defining factors of sustainable development should help to eliminate the conceptual problems and contradictions that arise in the process of integration of sustainable development principles in corporate activities, to contribute to the implementation of sustainable development principles into practice.

\section{Body of paper}

An analysis of publications on sustainable development leads to the conclusion about the formation of some common research approaches to studying the phenomenon of sustainable development: firstly, on the formation of the so-called triune approach (based on the idea of three bases of sustainable development (components, dimensions): economic, environmental and social); secondly, to expand the problematic field of research by including micro-economic aspects of sustainable development, i.e. challenges of companies sustainable development (microeconomic interpretation of sustainable development).

Correlation of sustainable development concept with social responsibility issues

Social responsibility of business had a long period of formation and development. Its theoretical foundation background one found in 1940s. Stakeholder approach emerged in the 1980 s and is one of the major approach nowadays. It allows us to determine the role of business, which takes into account interests of their own stakeholders and holds the voluntary responsibility for what is going beyond the obligations established by law. Socially responsible companies should care about consequences of principal activity of conducted business, to respond to pressing social problems and to take steps to improve the quality of life of stakeholders and society.

Stakeholder approach remains dominant in the field of social responsibility, and its implementation contributes to the accumulation of reputational capital, contributing to the growth of trust and loyalty of the company. The refusal of social responsibility is often equal to the refusal of sustainable development of business organization. For this reason, I consider social responsibility as one of the priority tasks of corporate management and one of the urgent modern economy problems (in terms of defining the role of social responsibility in the sustainable development of business organization and the contribution of social investment in sustainable development). Stability (as the company's ability to adapt to changing environment) acts as primary goal of sustainable development of business organization, marked by social responsibility.

The concept of sustainable development formed by the representatives of the Club of Rome at the end of 1960s and was actively reviewed at the end of 1980s - the beginning of 1990s, when they elaborated basic principles and understanding of sustainable development. The prerequisites for the scientific development in this direction included global crisis of humanity threat while the model of consumption and production is constant. As a consequence sustainable development is understood as satisfaction of the needs of current generation without compromising the same opportunity for future generations. In the 
classic sense the sustainable development is not adjustable to scale, and therefore it is not applicable to businesses. However, at the same time, representatives of business can and should contribute to sustainable development, as stated in the UN Global Compact.

Corporate sustainability first appears in the works of John Elkington. According to his point of view, corporate sustainability is a result of successful response of the company to actualized social demand. Corporate sustainability is in direct dependence on public pressure waves, affecting the business in different historical periods.

An equivalent of corporate sustainability was proposed by Wayne Visser. It is basic survival of business [3]. J. Elkington noted [4] that interest in global sustainable development and the ability of future generations to meet their needs is now at the same level as the current one. At the same time for them the corporate sustainability is vital. As an example Elkington analyses the 1973 oil crisis, when in a single day all members of OAPEC, and a number of other Arab countries stopped supplying countries that supported Israel during the Ramadan War (USA and its Western European allies) with oil, which resulted in four times rising oil prices in the subsequent year. Such a change caused the collapse of many companies working with hydrocarbon in one way or another.

Corporate sustainability in principle, is often understood as stability of financial flows. For example, M. Epstein treated it primarily as economic sustainability (long-term results) [5]. In this context, corporate sustainability can be defined as company's ability to maintain its competitiveness, profitability or breakeven, effective response to the threats and its interaction with factors of its external and internal environment [6].

Sustainable development of business organization. Radically new approach within the concept of sustainable development has been proposed in the article by J. Elkington "Towards the Sustainable Corporation: Win-Win-Win Business Strategies for Sustainable Development" [7]. Later, this concept was developed by other researchers, such as R. Steurer [8], T. Dyllick and K. Hockerts [9]. The fundamental difference of this direction is dissemination of the sustainable development concept from previous macro to micro level. Within this direction the sustainable development is analyzed from the corporation point of view, its risks and opportunities. These concepts and approaches, in our opinion, have a number of similarities:

Most of them have a triune approach (models triple bottom line, TBL, or 3BL) with its usual division into three areas: economic, environmental and social;

Business representatives are perceived as 'agents of change', taking responsibility for solving urgent problems of the society (including sustainable development issues such as responsible consumption and production, development of society and solving environmental problems) [10];

Responsibility of business is considered as a set of commitments of individual companies or entire business groups within the framework of decisions of socially important (stakeholder) issues at regional, national, and in some individual cases global levels;

In most cases they emphasize the principle of win-win strategy (general strategy of benefits), where the selected model of behavior is mutually beneficial both for business and for their stakeholders;

Some researchers view the company's sustainable development as a business model [11].

Stakeholder approach is used in almost all presented directions [12];

The term corporate sustainability is used in related approaches as the main condition for successful and long-term existence of business: achievement of sustainability (in particular financial), of competitiveness, of high capitalization and value of stock.

Contribution to the welfare of society or to part of it serves as one of the challenges of modern business (in this case they only change its scale from promoting global sustainable development to improvement of the quality of life of its own key stakeholders or local communities). 
In our view, such concepts and approaches as conscience economy, social economy, shared values concept, conscious capitalism and positive economy are quite close to the concept of social responsibility. Works by S. Overman, M. Porter and M. Kramer are currently subjected to a serious criticism as they have no fundamental differences from social responsibility or prominent scientific innovation in this direction. These approaches are duplicating each other, starting with principles of socially responsible behavior, and being, in fact, a logical development of economic thought on the revision of the business in society role.

Correlation of sustainable development concept with social responsibility issues remains an unresolved challenge for many researchers. Some authors consider this issue the position of sustainable development goals [13]. Some are exploring this issue from the Corporate Social Performance point [14]. Others are studying the impact of corporate social sustainability on financial success of a business organization [15]. But all these views have one thing in common - sustainable development of business organization is a direction, fitting into a new economic paradigm format. Sustainable development of business organization embraces the concept of corporate sustainability, which business can achieve as a result of its socially-oriented activities and contribution to the sustainable development of a whole society.

Features of non-financial sustainable development reporting of Russian corporations.

The interest of large Russian business organizations in standardization and certification of non-financial reporting is gradually increasing. Certification tasks of non-financial reporting are varied. The inclusiveness principle means that the information in the report corresponds to the key stakeholders interests. The inclusiveness principle means that the company must identify its own stakeholders, based on an integrated approach. Stakeholders should be involved in the process of identifying important aspects, procedures and mechanisms for measuring, monitoring and evaluation of communication [16].

The importance of provided information is certified by usage of objective information in the report. The report must demonstrate an understanding of the concept and include longterm objectives of sustainable development. It should be a balanced and reasonable presentation of information to stakeholders about essential economic, social and environmental aspects, determining business organization sustainable development aspects. Compliance with principle of responding to stakeholders' expectations means that shareholders interests and expectations are reflected in social activities and social policy priorities. The purpose of non-financial reporting certification is to identify its compliance with international accountability standards such as GRI (G4), AA1000 Stakeholder Engagement Standard (SES) 2011, AA1000 Assurance Standard (AS) 2008, Global Reporting Initiative Sustainability Reporting Guidelines) G3 2006 и G4 2013, International Standard on Assurance Engagement ISAE-3000 and ISO 26000:2010 Guidance on social responsibility. Some researchers view the standard SA 8000 as a tool for a sustainable development strategy [17]. Uncertified reports do not respond requirements of standards and can distort results of research.

Previously, various authors attempted to analyze non-financial reporting: about sustainability reporting and stakeholder engagement [18], influence of strategic corporate responsibility toward sustainability reporting [19], influence of corporate sustainability performance on sustainability reports [20], link between sustainable development and corporate financial performance [21], sustainability reporting standards [22], factors of nonfinancial reporting [23], analysis of sustainability strategy [24] and so on. I conducted a similar study of the problems of forming a sustainable development strategy for Russian companies [25]. All this became the basis for further methodological developments.

The analysis of non-financial reporting in the field of sustainable development of companies, declaring their commitment to the principles of sustainable development, has 
revealed features of the interpretation of sustainable development typical for Russian companies, as well as specific features of their approaches to the implementation of sustainable development principles. There we can reveal break of communicative principles, integrated and systemic sustainability of business organization. This allowed us to formulate the following topical issues of corporate activity in this area [21], tested on a number of academic and research conferences. Results of this study revealed following features of sustainable development, typical for Russian companies. Special reporting features in the field of sustainable development include:

- Absence of clear division of reporting types (reporting in the field of social responsibility and in the field of sustainable development);

- Substitution of social responsibility reports by sustainable development reports with no changes in its structure and content;

- High variability in selection of international standards in the field of non-financial reporting, and non-compliance with the inclusion principle of international standard GRI-4.

- Duplication of non-financial reporting in social responsibility by reporting on sustainable development;

- Focus in sustainable development reports on the social component sustainable development of business organization;

- Significant impact of the Company's core business on the content of reports, causing a breach of accountability standards principles (e.g AA1000APS 2008) related to the balance of the information provided;

- Missing common approach to the interpretation of the sustainable development of business organization, a variety of approaches to the understanding of the content of this concept and its associated concepts;

- Declarative, high degree of formalization of reports, substitution of notions, borrowings and stock phrases (cliché).

Unclear division of reports on corporate social responsibility and sustainable development leads to almost complete duplication of the content. In some cases, reports contained mixed titles, sometimes containing on its front page two titles, one of which belonged to the "social report" (or report on corporate social responsibility), and another to the sustainable "development report". The companies also freely use following names: "Sustainable Development Report", "Report on Corporate Sustainable Development" and the "Report on Corporate Sustainability", using these titles as absolute synonyms. This situation is an opposition to principles of hierarchy and systematicness of sustainable development of the business organization.

One can review statements imbalance within the social framework, a stronger focus of the sustainable development strategy focused on staff matters, internal environment of the company's problems. Weak economic and ecological direction means that businesses tend to avoid many of current challenges and opportunities. The tendency to support insider needs leads to defiance of environment, its threats and opportunities. This flatly contradicts hierarchical and systematic principles of sustainable development of business organization.

Substitution of non-financial reporting on social responsibility by sustainable development reporting is realizing without changes in its structure and considered directions. For example, the oil and gas sector issued the maximum number of reports on sustainable development, and at the same time did not provide any reports on social responsibility, the same situation is duplicated by the companies in the financial sector, which have released a large number if reports on sustainable development - much more in comparison to reports on social responsibility. Some companies simply combine reports on social responsibility and sustainable development (see e.g., "Sustainability Report and Social Responsibility in 2010" by the Company Tatneft'). Absence of fundamental changes in the reports structure and priorities in the field of sustainability reporting calls into question whether it is at all 
necessary. This transformation breaks principles of consistency and competence of sustainable development of business organization.

The main activity of the companies, as a rule, affects the content of the reports and, consequently, their positioning. For example, reports from the sector "Metallurgy and Mineral resource Industry" focus on safety issues (which may have caused by numerous accidents at mines in the mineral resource industry) and the negative impact of mineral industry on the population. However, the environmental issues for them are not a priority. Energy companies also paid maximum attention to environmental issues and the impact of main activities on biosphere and anthropogenic environment. Thus economic issues are considered in this case not in a priority position. This problem impeaches the possibility of implementing principles of balance, competence and systemic sustainable development of business organization.

There is a tendency to annual growth of the number of companies giving non-financial reporting on sustainable development, which raises the problem of accounting and compliance with international standards. Understanding sustainable development as a new stage following the corporate social responsibility (or social responsibility is reviewed under the umbrella-type concept of sustainable development) leads to the replacement of reporting on social responsibility by reporting on sustainable development. The study also reveals a trend toward transparency, accessibility of non-financial reports, their availability on the Internet for wide audience, which leads to the possibility of borrowing, plagiarism, the appearance of cliché and standard formulas. This trend is reflected in such principles of sustainable development of business organization as communication and feedback.

In a number of reports they do not define the concept of "sustainable development" or do not give any kind of preamble, which would provide explanations, goals of this form of reporting, company's corporate philosophy and its understanding of "sustainable development". This foreword or separate paragraph can have a significant impact on the implementation of the principle of sustainable development of business organization goalsetting.

\section{Conclusion}

In our opinion, the above-mentioned problems are associated with non-financial reporting and can be solved in the following ways.

It is necessary to take into account the fact of substitution and duplication of non-financial reporting on social responsibility by non-financial reporting of sustainable development and make a transition from this form to the integrated reporting, which will reflect social responsibility, the company's contribution to sustainable development and achievements in the field of corporate sustainability.

In the process of implementing the principles of sustainable development, business organization should equally consider social, environmental and economic areas. According to the study, environmental and economic aspects are least taken into account by them. Companies in order to achieve stability and to create safe conditions for sustainable development should focus on external and internal environment of the organization, avoiding giving clear preference for one of them. Only in this case, the company will have the ability to recognize the queries, actual problems and challenges of sustainability, to form a response to them (to implement the activities of new principles, standards and practices of relations with stakeholders), thereby achieving corporate sustainability and promoting sustainable development.

Substitution of reporting on social responsibility by reporting in the field of sustainable development is undesirable as among the business community there is no common 
understanding of sustainable development of business organization. Social responsibility report can also contain a wide range of information about the corporate culture, philosophy, and integration of social responsibility to the company's strategy.

In the process of the formation of sustainable development strategy the company should take into account the nature of main activity, which should not have an undue influence on the strategy, but only utilize its specifics. For example, companies operating in the extractive industries should not focus exclusively on problems of interaction with the environment, significantly reducing the priority of social needs and economic aspects. Also, it should be understood that according to the concept of sustainable development, there is no company, whose main activity does not have an environmental aspect (even if they do not carry out production operation).

The growing number of companies producing non-financial reporting on sustainable development, inevitably leads to compulsory formation of sustainable development strategy for large companies.

Information transparency and the increasing accessibility of corporate materials is another argument in favor of the formation of a sustainable development strategy. Accountability of non-financial reporting and its dissemination may be realized through independent internet portals (for instance Directory of non-financial reporting of the magazine "Sustainable Business") with the search system, systematization of reporting forms and the possibility of full-text access. Portals must supply the report with all the additional information about the nature of its certification and performance standards. It could be also a perspective step if they introduce our content analysis method on software level using automated systems and the ability to derive analytical results in a special section of the portal. Thanks to a longterm development of non-financial accounting register, certification procedures and civil control, the trend towards transparency, as expressed in non-financial reports for general use, should prevent companies from borrowings (plagiarism). In addition, the potential reputational side effects of the company in case of plagiarism will be higher than the cost of writing unique report.

Business organizations should develop their own understanding of terms such as "sustainable development", "sustainable development of business organization" and "social responsibility". In order to achieve business sustainability and promote sustainable development at the level of business globalization, representatives of the business community should develop a clear corporate philosophy, to implement the principles of sustainable development.

\section{References}

1. T. Dyllick, K. Hockerts, Beyond the Business Case for Corporate Sustainability. Business Strategy and the Environment 11, 130 (2002)

2. O.A. Kanaeva, Social imperatives of sustainable development. St Petersburg University Journal of Economic Studies 34, 26 (2018)

3. W. Visser, D. Matten, M. Pohl, N. Tolhurst, The A to Z of Corporate Social Responsibility: A Complete reference Guide to Concepts, Codes and Organisations (John Wiley \& Sons, Chichester, Hoboken, 2010)

4. W. Visser, D. Matten, M. Pohl, N. Tolhurst, The A to Z of Corporate Social Responsibility: A Complete reference Guide to Concepts, Codes and Organisations (John Wiley \& Sons, Chichester, Hoboken, 2010) 
5. M.J. Epstein, M.-J. Roy, Making the business case for sustainability. Linking social and environmental actions to financial performance. Journal of Corporate Citizenship 9, 79-96 (2003)

6. J.A. Bernal-Conesa, C. de Nieves Nieto, A.J. Briones-Peñalver, CSR strategy in technology companies: Its influence on performance, competitiveness and sustainability. Corporate Social Responsibility and Environmental Management 24, 96107 (2017)

7. J. Elkington, Towards the Sustainable Corporation: Win-Win-Win Business Strategies for Sustainable Development. California Management Review 36, 90 (1994)

8. R. Steurer, M.E. Langer, A. Konrad, A. Martinuzzi, Corporations, Stakeholders and Sustainable Development I: A Theoretical Exploration of Business-Society Relations. Journal of Business Ethics 61/3, 263-281 (2005)

9. T. Dyllick, K. Hockerts, Beyond the Business Case for Corporate Sustainability. Business Strategy and the Environment 11, 131 (2002)

10. J. Moon, The Contribution of Corporate Social Responsibility to Sustainable Development. Sustainable Development 15, 296-306 (2007)

11. M. Geissdoerfer, D. Vladimirova, S. Evans, Sustainable Business Model Innovation: A Review. Journal of Cleaner Production 198, 401-416 (2018)

12. K. Joensuu, M. Makela, T. Onkila, Contradictory stakeholder expectations for sustainability reporting - a social contract theory approach. Social Innovation And Sustainable Entrepreneurship, 39-61 (Edward Elgar Publishing Ltd, The Lypiatt, 2018).

13. L. Moratis, F. Melissen, How do the sustainable development goals question rather than inform corporate sustainability? Resources Conservation And Recycling 141, 253-254 (2019).

14. J. Burke, R. Hoitash, U. Hoitash, The Heterogeneity of Board-Level Sustainability Committees and Corporate Social Performance. Journal of Business Ethics 154, 11611186 (2019).

15. G. Schonborn, C. Berlin, M. Pinzone, C. Hanisch, K. Georgoulias, M. Minna, Why social sustainability counts: The impact of corporate social sustainability culture on financial success. Sustainable Production And Consumption 17, 1-10 (2019).

16. K.Yu. Belousov, Evolution of views on the role of stakeholders in the development system of the company: the problem of existing stakeholders. Problems of the modern economy 4, 418-422 (2013)

17. G.Santos, F. Murmura, L. Bravi, SA 8000 as a tool for a sustainable development strategy. Corporate Social Responsibility and Environmental Management 25, 95-105 (2018)

18. S. Romero, S. Ruiz, B. Fernandez-Feijoo, Sustainability reporting and stakeholder engagement in Spain: Different instruments, different quality. Business Strategy and the Environment 27, 221-232 (2018)

19. A. Amran, S.P. Lee, S. Devi, The influence of governance structure and strategic corporate social responsibility toward sustainability reporting quality. Business Strategy and the Environment 23, 217-235 (2014)

20. G. Braam, R. Peeters, Corporate sustainability performance and assurance on sustainability reports: Diffusion of accounting practices in the realm of sustainable development. Corporate Social Responsibility and Environmental Management 25, 164-181 (2017) 
21. M.J. Charlo, I. Moya, A.M. Muñoz, Sustainable development and corporate financial performance: A study based on the FTSE4Good IBEX Index. Business Strategy and the Environment 24, 277-288 (2015)

22. R.G. Eccles, M.P. Krzus, J. Rogers, G. Serafeim, The need for sector-specific materiality and sustainability reporting standards. Journal of Applied Corporate Finance, 24, 8-14 (2012)

23. C. Kitsikopoulos, U. Schwaibold, D. Taylor, Limited progress in sustainable development: Factors influencing the environmental management and reporting of South African JSE-listed companies. Business Strategy and the Environment 20, 12951301 (2018)

24. J. Whitehead, Prioritizing sustainability indicators: Using materiality analysis to guide sustainability assessment and strategy. Business Strategy and the Environment 26, 399412 (2017)

25. K.Yu. Belousov, Actual problems of the formation of a strategy for sustainable development of Russian companies. Problems of the modern economy 3, 191-194 (2013) 